\title{
Microscopic aspects of electrosensory system on the partially euryhaline lesser guitarfish
}

\author{
BIANCA S. RANGEL ${ }^{1,2}$, NATASCHA WOSNICK ${ }^{3}$, ALBERTO F. AMORIM ${ }^{4}$, \\ JOSÉ ROBERTO K. JUNIOR ${ }^{2}$ and ROSE E.G. RICI ${ }^{5}$
}

\author{
${ }^{1}$ Departamento de Fisiologia, Instituto de Biociências, Universidade de São Paulo, \\ Rua do Matão, Travessa 14, 321, 05508-090 São Paulo, SP, Brazil \\ ${ }^{2}$ Departamento de Cirurgia, Faculdade de Medicina Veterinária e Zootecnia, Universidade de São \\ Paulo, Rua Professor Orlando Marques Paiva, s/n, 05508-270 São Paulo, SP, Brazil \\ ${ }^{3}$ Departamento de Fisiologia, Setor de Ciências Biológicas, Centro Politécnico, Universidade Federal do Paraná, \\ Av. Coronel Francisco Heráclito dos Santos, s/n, Jardim das Américas, 81531-990 Curitiba, PR, Brazil \\ ${ }^{4}$ Núcleo de Pesquisa e Desenvolvimento, Instituto de Pesca, Agência Paulista de Tecnologia dos Agronegócios, Secretaria \\ de Agricultura e Abastecimento do Estado de São Paulo, Av. Bartolomeu de Gusmão, 192, 11030-906 Santos, SP, Brazil \\ ${ }^{5}$ Central de Facilidades à Pesquisa, Faculdade de Medicina Veterinária e Zootecnia, Universidade de \\ São Paulo, Rua Professor Orlando Marques Paiva, s/n, 05508-270 São Paulo, SP, Brazil
}

Manuscript received on December 21, 2015; accepted for publication on March 18, 2016

\begin{abstract}
The electrosensory system on elasmobranchs consists of subcutaneous electroreceptor organs known as ampullae of Lorenzini. The present study investigated the ampullae of Lorenzini morphology of the lesser guitarfish Zapteryx brevirostris, using light microscopy and scanning electron microscopy. The pore number found in the ventral skin surface is much higher than that found in the dorsal portion, characteristic of species that inhabit the euphotic zone. Under light microscopy it was possible to observe that the wall canal consists of a single layer of squamous epithelial cells. The canal features distal expansion, where the ampullae are located with up to six alveoli. The sensory epithelium of ampullae is composed by cubic cells, with oval nucleus, restricted to the interior of the alveoli. With analysis the clusters under scanning electron microscopy, it was possible to observe the structure and the random arrangement of individual ampullae, canals and nerves. The distribution of dorsal and ventral pores and ampullae in Z. brevirostris resembled those of the same family. The number of alveoli per ampullae was similar to that found in euryhaline elasmobranchs species, suggesting that the morphological organization in Z. brevirostris is linked to its possible evolutionary transitory position among batoids.
\end{abstract}

Key words: elasmobranch, ampullae of Lorenzini, electroreceptors, light microscopy, scanning electron microscopy.

\section{INTRODUCTION}

Elasmobranchs (sharks and rays) play a vital role in marine ecosystems since they occupy the

Correspondence to: Rose Eli Grassi Rici

E-mail: roseeli@usp.br apical portion of the food chain, being important regulators, especially in tropical and subtropical environments (Garrick 1982, Camhi et al. 1998, Stevens et al. 2000, Ferretti et al. 2010). All sharks and rays present an elaborate electrosensory system composed by groups of subcutaneous 
electroreceptors organs, known as "ampullae of Lorenzini" (aL). The system is composed by a complex web of nerve fibers, canals and external pores ranging in size, shape and composition, related to particular needs of each species (Murray 1960, Kajiura 2001, Wueringer and Tibbetts 2008, Kajiura et al. 2010, Wueringer et al. 2011, 2012, Kempster et al. 2012, Bedore et al. 2014).

The ability to detect weak bioelectric fields evolved independently in several lines of vertebrates, emphasizing the importance of this sense in a variety of behaviors (Bullock et al. 1983, Collin 2010, 2012). Phylogenetically, it is considered an ancient sensory modality (Wilkens and Hofmann 2005). The role of the electrosensory system can be multifunctional, facilitating social and reproductive behaviors (Tricas et al. 1995, Sisneros and Tricas 2002), predator detection (Sisneros et al. 1998) and navigation/guidance through the Earth's magnetic field (Kalmijn 1971, Paulin 1995, Montgomery and Walker 2001, Krylov et al. 2014). Its main role however, is prey detection (Kalmijn 1971, Kalmijn and Weinger 1981, Raschi 1986, Tricas 1982, Kajiura 2001, Bedore et al. 2014).

The canal length and pore distribution are the two main characteristics that determine ampullae sensitivity in a uniform field (Kalmijn 1971, Tricas 2001). The distribution and density on the body surface is influenced by environment, diet composition, predatory behavior and phylogenetic position (Wueringer et al. 2009, Kempster et al. 2012). In batoids, the canals extend over the ventral surface to the end of the dorsal fins, with the highest density around the mouth (Jordan 2008).

Rhinobatidae species are popularly known as "guitarfishes" being the earliest representatives of current skates and rays, with fossil records dating back to the Jurassic period (McEachran et al. 1996, Shirai 1996). The family is comprised of four genera (Aptychotrema; Rhinobatos; Trygonorrhina and Zapteryx) and 45 species (Compagno 2005). In
Brazil, two genera and four species can be found: Rhinobatos horkelii (Müller and Henle 1841); $R$. lentiginosus (Garman 1880); R. percellens (Walbaum 1792), and Zapteryx brevisrostris (Müller and Henle 1841) (Figueiredo 1977).

Zapteryx brevirostris, popularly known as the lesser guitarfish, distinguish itself from other guitarfish by presenting a shorter rostrum. The species is endemic to the Southwest Atlantic, with a relatively restricted distribution, occurring from Espírito Santo (Brazil) to Argentina (Figueiredo 1977, Vooren et al. 2006). It is commonly found at depths of $60 \mathrm{~m}$ (Figueiredo 1977) and feed on small animals such as Polychaeta and decapod crustaceans (Bornatowski et al. 2014). Tons of individuals are accidentally caught and discarded annually (Vooren et al. 2006). Classified as vulnerable by the IUCN Red List, the species is currently unprotected, fact that can lead an irreversibly reduction in stock in the next years (Vooren et al. 2006).

Currently, studies with Z. brevirostris are focused on reproduction (Abilhoa et al. 2007), distribution (Santos et al. 2006) and food chain position (Bornatowski et al. 2014), without any analysis of sensory systems, even with the relatively high predatory position featured in marine environments (Bornatowski et al. 2014). In this context, the aim of this study was to analyze the morphology of ampullae of Lorenzini in $Z$. brevirostris using light microscopy (LM) and scanning electron microscopy (SEM), providing detailed information about this important predation system.

\section{MATERIALS AND METHODS}

\section{ANIMALS}

Shrimp trailers operating in Southeastern Brazil, between depths of 15-70 m, accidentally caught ten adults. The specimens were donated to the Department of Surgery of Veterinary Medicine and Animal Science of the University of São Paulo, under permission from SISBIO 48271-1. The 
project was approved by the Ethics Committee on Animal Use (CEUA) (Protocol No 2330141113FMVZ/USP).

\section{MACROSCOPY}

For detection and analysis of pore distribution, the animals were placed dorsally. For hyoid cluster detection, the dissection of the ventral region was performed just above the first gill pair, guided by morphological descriptions of guitarfish published by Wueringer and Tibbetts (2008). The images were documented with a digital camera (Nikon D3100).

\section{LIGHT MICROSCOPY (LM)}

For light microscopy, hyoid cluster samples from five adult specimens were used. The samples were fixed in 4\% paraformaldehyde. After complete fixation, the samples were dehydrated in ascending ethanol series (from $70 \%$ to $100 \%$ ) and cleared in xylene for subsequent embedding in paraplast. Paraplast blocks were sectioned $(5 \mu \mathrm{m})$ using a microtome (Leica-German), and then stained with Hematoxylin-Eosin (HE) and Masson Trichrome (MT). Analysis was performed using a light microscope (Nikon Eclipse E-800).

\section{SCANNING ELECTRON MICROSCOPY (SEM)}

Samples from the skin of ventral region, the rostrum and the hyoid cluster of five adult specimens were fixed in $10 \%$ formaldehyde solution, dehydrated in series of increasing ethanol concentration $(70 \%$ to $100 \%$ ). After dehydration, the samples were dried in a Balzers CPD 020 critical-point device mounted onto metal stubs with carbon adhesive and sputtered with gold in an Emitech K550 sputter apparatus. Finally, the samples were photographed in a LEO 435VP scanning electron microscope.

\section{RESULTS}

The aL pores were easily identified in the ventral part of the body due to color difference (lighter in this region) (Fig. 1a). The ventral portion present a higher number of pores, especially close to the mouth and in the rostral cartilage, extending to the anterior half of the pectoral fins (Fig. 1a). Both free and clustered ampullae were detected, surrounded by connective tissue, being also possible to observe the emergence of a nerve that extends to the anterior lateral line nerve (branch of cranial nerve VII) (Fig. $1 \mathrm{~b}$ and $1 \mathrm{c})$. The hyoid cluster is the largest, found laterally to the jaw and close to the gills on the ventral side and laterally to the eye in the dorsal region (Fig. 1a and $1 b$ ).

In the analysis of the dorsal region skin under SEM, the arrangement and shape of dermal denticles were evidenced, being different in both size and position according to their distance to the pores of the ampullae (Fig. 1d). Dermal denticles feature a smooth crown, with irregularly shaped borders, varying in major and minor asymmetrical lobes, resembling morphology of leaves from an oak tree.

In the cross section of the rostrum, under SEM, the location and arrangement of the longitudinal canals (in relation to the surface of the ventral region were detected) (Fig. 1e). The threedimensional aspect of the hyoid cluster reveals the $\mathrm{aL}$ arrangement and the canals entrances parallel to each other (Fig. 2a and 2b). Through the hyoid cluster analysis it was possible to observe the covering structure of the capsule (Fig. 2b). In the base of the canal, the aL was detected (Fig. 2c) as an ovoid capsule with a nerve originating from its base (Fig. 2a).

Under light microscopy, it was possible to observe that the ampullae are distributed randomly in the cluster. The cross section (Fig. 2d and 2e) and sagittal section (Fig. $2 \mathrm{f}$ and $2 \mathrm{~h}$ ) facilitated structural visibility of ampullae (canal, bulb and nerve). The aL observed are multialveolar, according to the classification proposed by Andres and von Düring (1988). 

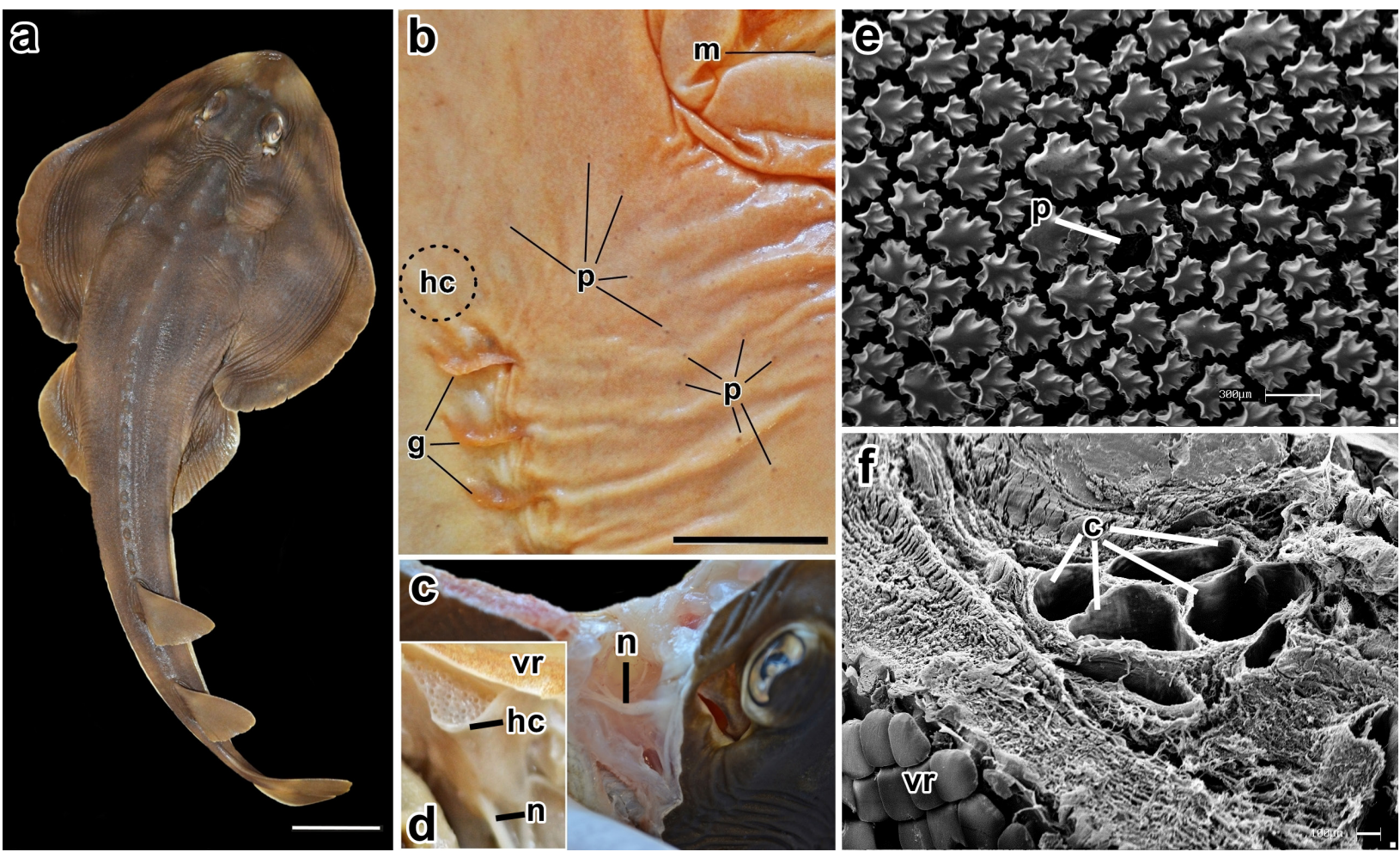

Figure 1 - (a) macrograph of the ray Zapteryx brevirostris. (b) the ventral region, showing the location and disposition of some pores (p) located near the gills $(\mathrm{g})$ and mouth $(\mathrm{m})$; dashed circulated region, represents the location of hyoid cluster (hc). (c) nerve (n) of hyoid cluster. (d) hyoid cluster (hc) located next to the gills and nerve (n); ventral region (vr). (e) disposition of the denticles and pores (p) in the skin of the rostral dorsal region, where the denticles around the pores are smaller and differentiated. (f) cross section of the rostrum, location in relation to the region ventral skin (vr) and longitudinal arrangement of the ampullae canals (c). Scale bars: (a) $5 \mathrm{~cm}$; (b) $2 \mathrm{~cm}$; (e) $300 \mu \mathrm{m}$; (f) $100 \mu \mathrm{m}$.

The analyzed ampullae consisted in a group at maximum six alveoli (Fig. 2d), covered with connective tissue. At the distal end of the alveoli, it was possible to observe the aL nerve (Fig. $2 \mathrm{f}$ and $2 \mathrm{~h}$ ). The receptor epithelium of the ampullae (restricted to the alveoli) is formed by a monolayer of simple cuboidal cells with oval nuclei (Fig. 2i). The canals observed in transverse and sagittal sections are randomly distributed in the hyoid cluster, separated by connective tissue (Fig. 2g). The walls of canals are composed by squamous epithelial cells.

\section{DISCUSSION}

The present study brings the identification and description of morphological characteristics of the electrosensory system in Z. brevirostris.
The analysis are relevant and important since this sensory system is fundamental for animal's survival and hunting adaptation. Our results showed a higher number of pores on the ventral surface of the skin compared to the dorsally portion. The observed distribution is advantageous not only because most of $Z$. brevirostris preys are found buried, but also because other senses are not as well developed as in pelagic animals. Batoids are flattened dorsoventrally with mouth positioned ventrally while the eyes occupy a dorsal position. That way, batoids little depend on vision during hunting, since most of the preys are buried (Raschi 1986). According to Kempster et al. (2012), the benthic zone is a two-dimensional environment, and the majority of the species live on the bottom or very near to the substrate. Under these conditions, 

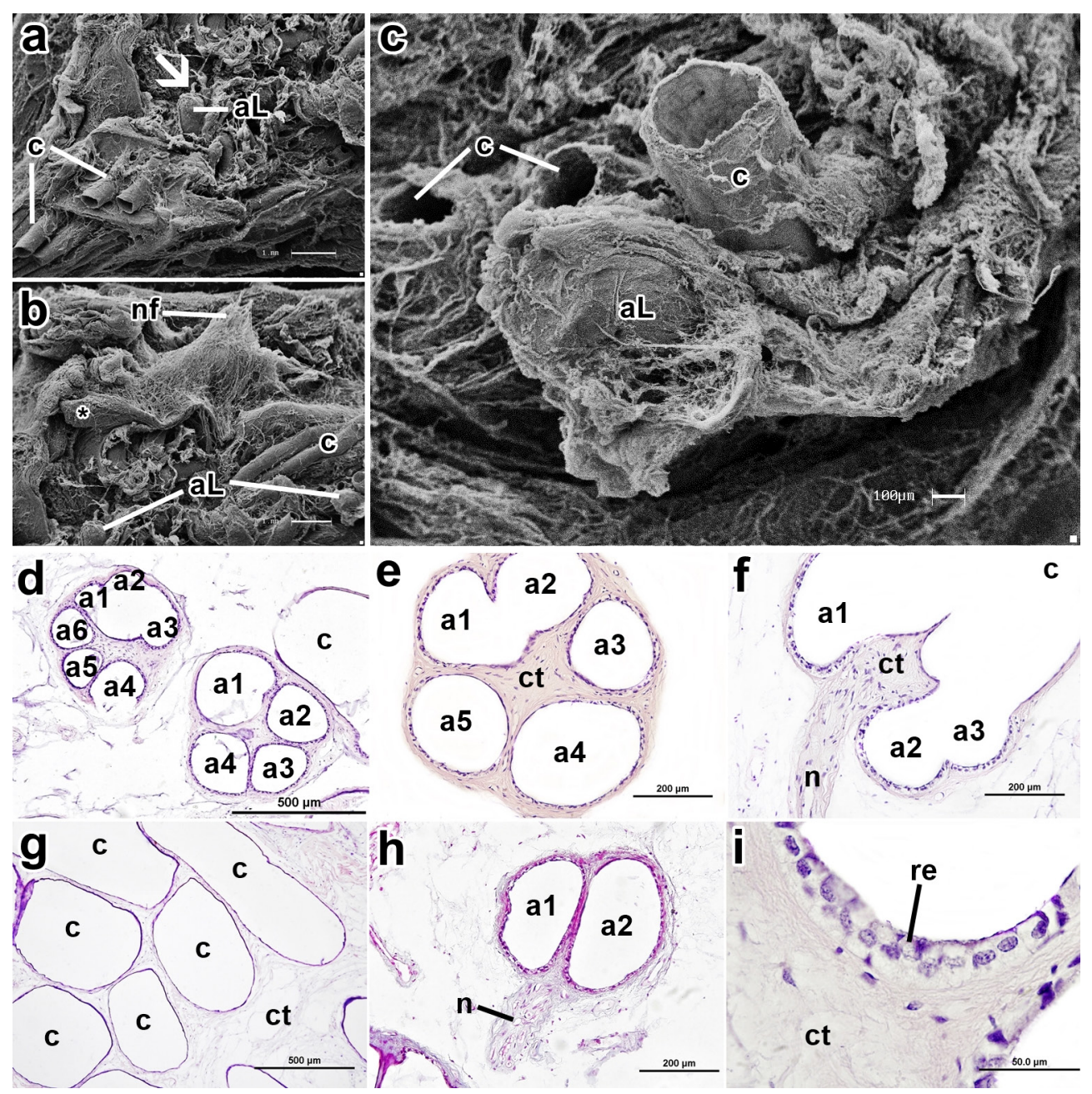

Figure 2 - Hyoid cluster microscopy. (a, b and c) disposition and parallel of input canals (c) and location of the ampullae of Lorenzini $(\mathrm{aL})$ in the hyoid cluster; $(*)$ capsule coating the hyoid cluster. (d, e and f) in HE staining the vials in cross section, covered with connective tissue (ct), with up to six alveoli (a1-a6) and canal (c). (g) canals at random in sagittal and transverse sections, separated by connective tissue (ct). (h) in TM staining, ampullae in sagittal section with visible nerve (n) (i) in HE staining the receptor epithelium (re) in largest magnification formed by cubic cells and oval nucleus. Scale bars: (a) $500 \mu \mathrm{m}$; (b-f) $200 \mu \mathrm{m}$; (g) $100 \mu \mathrm{m}$; (h and i) $50 \mu \mathrm{m}$.

animals are generally slow, with limited range, often displaying cryptic camouflage. To compensate visual inefficiency, benthic predators have become quite dependent of the electrosensory system, with a higher proportion of pores in the ventral portion of the body. Pores are more common around the mouth, position probably related to the need of orientation for animal's mouth during capture (Raschi 1986, Jordan 2008, Wueringer et al. 2011, Kempster et al. 2012).
For sawfish (Pristis sp.) (Wueringer et al. 2011) it was suggested that the high density of pores over the rostrum and low around the mouth may be an indication of the use of rostrum to stun prey before ingesting. This may be an indication of pore distribution plasticity due to hunting behavior and feeding habits. The elongated rostrum found in guitarfish may be related to the need to increase sensory area/information, with numerous ampullary clusters observed in the rostral region 
in Rhinobatidae (Wueringer and Tibbetts 2008). Therefore, it is possible that the spatial distribution for guitarfishes have the same function/importance of that observed in sawfishes. Based on this hypothesis, we can infer that $Z$. brevirostris has a lower electrosensory sensitivity compared with other species of guitarfishes, due to the absence of the elongated rostrum. Nevertheless, more studies that characterize the distribution and density are needed, since it is possible that the rostrum shortening is compensated in other ways.

For Kajiura et al. (2010), the importance of electroreception decreases with increased water clarity. Rhinobatos tyus and Aptychotrema rostrata, both guitarfishes, live deeper environments (100 $\mathrm{m}$ ) with lower luminosity, while $Z$. brevirostris live in lesser depth (up to $60 \mathrm{~m}$ ) and lighter environments. $R$. tyus and A. rostrate feature longer rostrum, possibly related to the need to increase electrosensory sensitivity due to the reduced vision ability, while $Z$. brevirostris does not depend that much on electrosensory system since the species lives in environments with higher visibility. The species also possible to observe a large number of pores surrounding the gills. This distribution many be related to the use of water expelled through the slits to move the substrate, thus facilitating the perception of buried prey. The behavior of using spiracle movements for other purposes besides the respiratory function has already been described (Tricas et al. 1995), thus being reasonable to infer that $Z$. brevirostris can also use the expulsion of water through the slits for other purposes.

The distribution described for $Z$. brevirostris resembles that seen in Dasyatis sp. known as active swimmers and spending brief periods buried, presenting little or no dependence on the presence of a rostrum for predatory purposes (Bedore et al. 2014). This leads us to believe that the rostral region of $Z$. brevirostris lost its importance during evolutionary process, which could be indicative of a transitional adjustment between guitarfish with elongated rostrum and skates and rays without rostral portion.

Since the sensorial epithelium is sensitive to voltage gradients created between the environment and the interior of the ampullae, sensitivity increases with canal length (Murray 1974). The elongate canals observed in the dorsal fins of guitarfish may facilitate the detection of weak electric fields at longer distance, allowing that way, the initial location of prey. On the other hand, the shorter canals found in the rostrum and near to the mouth may present a lower range of perception, being probably used for detection of the precise position of prey on short range (Tricas and New 1998, Wueringer and Tibbetts 2008).

Few studies emphasizing the microscopic features are available for a very small portion of species, even though great diversity in the system is found in elasmobranchs (Wueringer and Tibbetts 2008, Wueringer et al. 2009, Camilieri-Asch et al. 2013, Whitehead et al. 2014). These studies suggest that the canals that come out of the pores both in ventral and dorsal regions, come together close to cluster areas. The nerve is located laterally to the entrance of the canals in the cluster, same as observed by Wueringer (2012). This is the largest cluster present in batoids (Raschi 1978, Wueringer and Tibbetts 2008, Wueringer et al. 2011) being absent in Carcharhiniformes and Lamniformes sharks (Raschi 1986). Guitarfish and sawfishes features five bilaterally symmetric clusters (Norris 1929 cited Wueringer 2012, Wueringer and Tibbetts 2008, Wueringer et al. 2011).

Zapteryx brevirostris possess macromultialveolar ampullae, which are commonly found in marine elasmobranchs (Andres and von Düring 1988). Even being classified as marine, Z. brevirostris present a number of alveoli per ampullae close to guitarfishes found in estuaries ( $A$. rostrata, average of $6 \pm 0.7)$, lower compared with marine guitarfishes ( $R$. typus present an average of $17.0 \pm 5.8$ alveoli per ampullae) (Wueringer and 
Tibbetts 2008). The same amount of alveoli it is also observed in Carcharhinus leucas, famously known for its high adaptive capacity in freshwater environments (Pillans and Franklin 2004, Pillans et al. 2006). Bull sharks also present other morphological similarities in aL distinct from other elasmobranchs (Whitehead et al. 2014), so it is possible that differences observed are salinity dependents. The same pattern is in Pristis microdon during the juvenile stage, spent in lower salinity environments (Wueringer et al. 2011).

A study of two sympatric species of rays revealed that Dasyatis fluviorum, considered euryhaline, presents morphological characteristics in the electrosensory system similar to Neotrygon kuhlii, a marine species (Camilieri-Asch et al. 2013), being the morphological differences observed, possibly related to habitat differences (Camilieri-Asch et al. 2013). The number of alveoli found in $Z$. brevirostris also resembles the results found in D. fluviorum, which present 6-10 wells per ampullae.

Therefore, it is possible to infer, based on morphological similarity and the number of alveoli per ampullae between $Z$. brevirostris and $A$. rostrata (Wueringer et al. 2009), C. leucas (Whitehead et al. 2014), P. microdon (Wueringer et al. 2011) and D. fluviorum (Camilieri-Asch et al. 2013), that the strong link based on electrosensory system is a relevant evidence for at least partial euryhalinity in Z. brevirostris currently described as exclusively marine (IUCN, Fishbase).

Studies show that in fact, Z. brevirostris has high physiological plasticity facing different salinities in laboratory experiments (Wosnick and Freire 2013). Since the species is not found in estuaries (Chaves and Correa 1998), it is possible that this ability is related to the evolutionary past of the group, possibly in brackish environments (Smith 1936, Lutz 1975, Griffith 1985, Ditrich 2007). That said, Z. brevirsotris might be an evolutionarily transitional species, not only because of the reduced importance of the rostrum compared to other benthic species, but also because of the electrosensory system organization.

\section{CONCLUSIONS}

The distribution of pores, canals and ampullae for $Z$. brevirostris resembled the pattern observed in other guitarfishes. However, it is possible that the reduction of the rostral region, combined with a higher amount of pores near the mouth and gills are transitional adjustments between benthic and pelagic rays.

The number of alveoli per ampullae was similar to that found in euryhaline species, suggesting that such morphological differences are linked to its possible evolutionary transition position, presenting physiological and morphological characteristics that make us believe that the species represents a mark in the evolutionary past of the group in lower salinity environments.

\section{ACKNOWLEDGMENTS}

We would like to thank the Conselho Nacional de Desenvolvimento Científico e Tecnológico (CNPq) for Scientific initiation scholarship, the postgraduate program of Departamento de Cirurgia, Faculdade de Medicina Veterinária e Zootecnia da Universidade de São Paulo and at postgraduate program in aquaculture and fishing for Instituto de Pesca.

\section{REFERENCES}

ABILHOA V, BORNATOWSKI H AND OLIVEIRA FREITAS M. 2007. Some information on reproduction and embryonic development of the lesser guitarfish Zapteryx brevirostris in Southern Brazil. Acta Adriat 48: 185-190.

ANDRES KH AND VON DÜRING M. 1988. Comparative anatomy of vertebrate electroreceptors. Prog Brain Res 74: 113-131.

BEDORE CN, HARRIS LL AND KAJIURA SM. 2014. Behavioral responses of batoid elasmobranchs to preysimulating electric fields are correlated to peripheral sensory morphology and ecology. Zoology 117: 95-103. 
BORNATOWSKI H, WOSNICK N, CARMO WPD, CORRÊA MFM AND ABILHOA V. 2014. Feeding comparisons of four batoids (Elasmobranchii) in coastal waters of southern Brazil. J Mar Biol Assoc UK 1: 1-9.

BULLOCK TH, BODZNICK DA AND NORTHCUTT RG. 1983. The phylogenetic distribution of electroreception: evidence for convergent evolution of a primitive vertebrate sense modality. Brain Res Rev 6: 25-46.

CAMHI MD, FOWLER S, MUSIK J, BRAUTIGAM A AND FORDHAM SV. 1998. Sharks and their relatives. Ecology and conservation. Occasional papers of the IUCN species survival commission 20: 39.

CAMILIERI-ASCH V, RYAN M, KEMPSTER RM, COLLIN SP, JOHNSTONE RW AND THEISS SM. 2013. A comparison of the electrosensory morphology of a euryhaline and a marine stingray. Zoology 116: 270-276.

CHAVES PTC AND CORRÊA MFM. 1998. Composição ictiofaunística da área de manguezal da Baía de Guaratuba, Paraná, Brasil. Rev Bras Zool 15: 195-202.

COLLIN SP. 2010. Electroreception in vertebrates and invertebrates. In: Breed MD and Moore J (Eds), Encyclopedia of Animal Behavior. vol I. Oxford: Academic Press, p. 611-620.

COLLIN SP. 2012. The Neuroecology of Cartilaginous Fishes: Sensory Strategies for Survival. Brain Behav Evol 80: 8096.

COMPAGNO LJV. 2005. Checklist of Living Chondrichthyes. In: Hamlett WC (Ed), Reproductive Biology and Phylogeny of Chondrichthyes. Sharks, Batoids and Chimaeras, Plymouth, UK: Science Publishers Inc., p. 503-548.

DITRICH H. 2007. The origin of vertebrates: a hypothesis based on kidney development. Zool J Linnean Soc 150: 435-441.

FERRETTI F, WORM B, BRITTEN GL, HEITHAUS M AND LOTZE H. 2010. Patterns and ecosystem consequences of shark declines in the ocean. Ecol Lett 13: 1055-1071.

FIGUEIREDO JL. 1977. Manual de peixes marinhos do Brasil - introdução: cações, raias e quimeras. Museu de Zoologia, Universidade de São Paulo. São Paulo, 105 p.

GARRICK JAF. 1982. Sharks of the genus Carcharhinus. NOAA Technical Report NMFS, Circular 445: 1-194.

GRIFFITH RW. 1985. Habitat, phylogeny and the evolution of osmoregulatory strategies in primitive fishes. In: Foreman RE, Gorbman A, Dodd JM and Olsson R (Eds), Evolutionary Biology of Primitive Fishes. New York: Plenum Press, p. 69-80.

JORDAN LK. 2008. Comparative morphology of stingray lateral line and electrosensory systems. J Morphol 269: 1325-1339.

KAJIURA SM. 2001. Head morphology and pore distribution of carcharhinid and sphyrnid sharks. Environ Biol Fishes 61: $125-133$.
KAJIURA SM, CORNETT AD AND YOPAK KE. 2010. Sensory adaptations to the environment: electroreceptors as a case study. In: Carrier JC, Musick JA and Heithaus MR (Eds), Biology of Sharks and Their Relatives, vol. II. Boca Raton: CRC Press, p. 393-434.

KALMIJN AJ. 1971. The electric sense of sharks and rays. J Exp Biol 55: 371-383.

KALMIJN AJ AND WEINGER M. 1981. An electrical simulator of moving prey for the study of feeding strategies in sharks, skates, and rays. Ann Biomed Eng 9: 363-367.

KEMPSTER RM, MCCARTHY ID AND COLLIN SP. 2012. Phylogenetic and ecological factors influencing the number and distribution of electroreceptors in elasmobranchs. $\mathrm{J}$ Fish Biol 80: 2055-2088.

KRYLOV VV, IZYUMOV YUG, IZVEKOV EL AND NEPOMNYASHCHIKH VA. 2014. Magnetic Fields and Fish Behavior. Biol Bull Rev 3: 222-231.

LUTZ PL. 1975. Adaptive and evolutionary aspects of the ionic content of fishes. Copeia 2: 369-373.

MCEACHRAN JD, MIYAKE T AND DUNN KA. 1996. Interrelationships of the batoid fishes (Chondrichthyes: Batoidea) In: Stiassny MLJ, Parenti LR and Johnson GD (Eds), Interrelationships of fishes. New York: Academic Press, p. 63-84.

MONTGOMERY J AND WALKER M. 2001. Orientation and navigation in elasmobranchs: which way forward? Environ Biol Fishes 60: 109-116.

MURRAY RW. 1960. Electrical sensitivity of the ampullae of Lorenzini. Nature 187: 957.

MURRAY RW. 1974. The ampullae of Lorenzini. In: Fessard A (Ed), Handbook of sensory physiology, vol III/3. Berlin: Springer, p. 125-146.

NORRIS HW. 1929. The distribution and innervation of the ampullae of Lorenzini of the dogfish, Squalus acanthias. Some comparisons with conditions in other plagiostomes and corrections of prevalent errors. J Comp Neurol 47: 449-465.

PAULIN M. 1995. Electroreception and the compass sense of sharks. J Theor Biol 174: 325-339.

PILLANS RD, ANDERSON WG, GOOD JP, HYODO S, TAKEI Y, HAZON N AND FRANKLIN CE. 2006. Plasma and erythrocyte solute properties of juvenile bull sharks, Carcharhinus leucas, acutely exposed to increasing environmental salinity. J Exp Mar Biol Ecol 331: 145-157.

PILLANS RD AND FRANKLIN CE. 2004. Plasma osmolyte concentrations and rectal gland mass of bull sharks Carcharhinus leucas, captured along a salinity gradient. Comp Biochem Physiol A 138: 363-371.

RASCHI WG. 1978. Notes on the Gross Functional Morphology of the Ampullary System in Two Similar Species of Skates, Raja erinacea and $R$. ocellata. Copeia 1: 48-53. 
RASCHI WG. 1986. A morphological analysis of the ampullae of Lorenzini in selected skates (Pisces, Rajoidei). J Morphol 189: 225-247.

SANTOS C, CORTELlETE GM, ARAÚJO KCB AND SPACH HL. 2006. Estrutura populacional da raia-viola Zapteryx brevirostris (Chondrichthyes, Rhinobatidae), na Plataforma adjacente à Baía de Paranaguá, PR. Acta Biol Leop 28: 32-37.

SHIRAI S. 1996. Phylogenetic interrelationships of Neoselachian (Chondrichthyes: Euselachii). In: Stiassny MLJ, Parenti LR and Johnson GD (Eds), Interrelationships of fishes. New York: Academic Press, p. 9-32.

SISNEROS JA, TRICAS TC AND LUER CA. 1998. Response properties and biological function of the skate electrosensory system during ontogeny. J Comp Physiol 183A: 87-99.

SMITH HW. 1936. The retention and physiological role of urea in the Elasmobranchii. Biol Rev 11: 49-82.

STEVENS JD, BONFIL R, DULVY NK AND WALKER PA. 2000. The effects of fishing on sharks, rays, and chimaeras (chondrichthyans), and implications for marine ecosystems. ICES J Mar Sci 57: 476-494.

TRICAS TC. 1982. Bioelectric-Mediated Predation by Swell Sharks, Cephaloscyllium ventriosum. Copeia 4: 948-952.

TRICAS TC. 2001. The neuroecology of the elasmobranch electrosensory world: why peripheral morphology shapes behavior. Environ Biol Fishes 60: 77-92.

TRICAS TC, MICHAEL SW AND SISNEROS JA. 1995. Electrosensory optimization to conspecific phasic signals for mating. Neurosci Lett 202: 29-131.

TRICAS TC AND NEW JG. 1998. Sensitivity and response dynamics of electrosensory primary afferent neurons to near threshold fields in the round stingray. J Comp Physiol 182A: 89-101.

VOOREN CM, LAMÓNACAAF, MASSA A AND HOZBOR N. 2006. Zapteryx brevirostris. In: IUCN 2014. IUCN Red
List of Threatened Species. Version 2014.1. Available at www.iucnredlist.org. (accessed 26, June 2014).

WHITEHEAD DL, GAUTHIER ARG, MU EWH, BENNETT MB AND TIBBETTS IR. 2014. Morphology of the Ampullae of Lorenzini in Juvenile Freshwater Carcharhinus leucas. J Morphol 276(5): 1-13.

WILKENS LA AND HOFMANN MH. 2005. Behavior of animals with passive, low-frequency electrosensory systems. In: Bullock TH, Hopkins CD, Popper AN and Fay RR (Eds), Electroreception. Springer Handbook of Auditory Research, vol 21. New York: Springer, p. 229263.

WOSNICK NAND FREIRE CA. 2013. Some euryhalinity may be more common than expected in marine elasmobranchs: The example of the South American skate Zapteryx brevirostris (Elasmobranchii, Rajiformes, Rhinobatidae). Comp Biochem Physiol Part A 166: 36-43.

WUERINGER BE. 2012. Electroreception in elasmobranchs: sawfish as a case study. Brain Behav Evol 80: 97-107.

WUERINGER BE, PEVERELL SC, SEYMOUR J, SQUIRE SL, KAJIURA SM AND COLLIN SP. 2011. Sensory systems in sawfishes. 1. The ampullae of Lorenzini. Brain Behav Evol 78: 139-149.

WUERINGER BE, SQUIRE SL, KAJIURA SM, TIBBETTS IR, HART NS AND COLLIN SP. 2012. Electric Field Detection in Sawfish and Shovelnose Rays. PLoS ONE 7(7): e41605.

WUERINGER BE AND TIBBETTS IR. 2008. Comparison of the lateral line and ampullary system of two species of shovelnose ray. Rev Fish Biol 18: 47-64.

WUERINGER BE, TIBBETTS IR AND WHITEHEAD DL. 2009. Ultrastructure of the ampullae of Lorenzini of Aptychotrema rostrata (Rhinobatidae). Zoomorphol 128: 45-52. 